\author{
Scripta : Jurnal Teologi dan Pelayanan \\ ISSN 2086-5368 (Print) \\ ISSN 2722-8231 (Online) \\ Http://ejournal.stte.ac.id \\ Vol.10, No.2, pp. 100-118, 2020
}

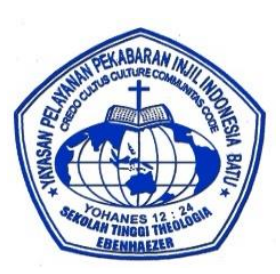

STT Ebenhaezer

Tanjung Enim

\title{
Perempuan Yang Bersyukur Menurut Alkitab Dan Implementasinya Bagi Kaum Wanita Hedonis
}

Elisa Sihombing, Jeane Paath

${ }^{1}$ Rohaniawan Gereja Kristen Protestan Angkola (GKPA) Padangsidimpuan Barat,

2Dosen STT Ebenhaezer Tanjung Enim, paathjeane@gmail.com

\section{INFO ARTIKEL \\ Sejarah Artikel: \\ Diterima : 28-10-2020 \\ Direvisi : 25-11-2020 \\ Disetujui: 26-11-2020 \\ Dipublikasi: 28-11-2020}

Kata Kunci:

Perempuan,

Bersyukur, Alkitab,

Wanita, Hedonis

Keywords:

Female, Gratefule, Bible, Woman, Hedonist

\begin{abstract}
ABSTRAK
Perempuan yang bersyukur saat ini menjadi sebuah situasi yang sulit dilakukan oleh wanita dalam hidupnya. Kaum wanita hedonis karena tidak hanya merugikan secara rohani, namun juga karakter dan kepribadian individu. Oleh sebab itu penerapan perempuan bersyukur menurut Alkitab sangat penting bagi wanita yang hedonis dan tidak bersyukur dengan melalui pemahaman Firman Tuhan yang benar, mengetahui hakikatnya sebagai umat Allah. Firman Tuhan merupakan kebenaran yang akan menuntun orang percaya untuk serupa dengan Kristus Yesus. Kaum wanita hedonis yang tidak bersyukur telah terjadi di berbagai kalangan. Ini merupakan situasi yang memprihatikan, penurunan kualitas secara rohani, dan moral tentunya akan berpengaruh terhadap gereja. Berangkat dari problematika tersebut, jelas bahwa wanita hedonis sangat membahayakan. Dengan pendekatan kualitatif dan metode deskriptif-theologis dalam skripsi ini penulis memberikan implementasi bagi kaum wanita hedonis, sehingga hasil studi ini dapat menjadi acuan bagi kaum wanita dalam meningkatkan kualitas rohaninya.
\end{abstract}

\section{ABSTRACT}

Today a grateful woman is a situation that is difficult for women to do in her life. Women are hedonistic because they are detrimental not only spiritually, but also individual character and personality. Therefore, the application of women who are grateful according to the Bible is very important for women who are hedonistic and ungrateful by understanding the true Word of God, knowing their essence as God's people. God's Word is the truth that will lead believers to be like Christ Jesus. Hedonist women who are not grateful have occurred in various circles. This is a situation of concern, spiritual and moral deterioration will certainly affect the church. Departing from these problems, it is clear that hedonistic women are very dangerous. With a qualitative approach and descriptive-theological methods in this thesis, the authors provide an implementation for hedonic women, so that the results of this studycan be a reference for women in improving their spiritual quality.The second abstract is written in English. Abstract length 
maximum 250 words. At least the abstract should include the background of the study, research methods, research results and recommendations. The abstract should include two to five keywords, and the format of writing follows the template.

\section{PENDAHULUAN}

Manusia diciptaan Tuhan menurut gambar dan rupa Allah yang sangat istimewa di antara ciptaan lainnya (Kejadian 1:26-27), semua manusia adalah rupa dari Allah dan mirip dengan Allah. Tentu kemiripan ini tidak terjadi dalam segala hal, karena Allah mempunyai sifat-sifat yang tidak ada dimiliki manusia. Allah juga memberi nafas hidup kepada manusia yang menjadikan sebagai makhluk rohani, hal ini menyebabkan manusia bersekutu dengan Allah, berdoa, mendengarkan Firman Tuhan, berbakti kepada Tuhan karena sudah dicipta sebagai makhluk yang begitu tinggi dan mulia.

Richard L. Pratt mengatakan bahwa semua ciptaan Allah itu amat sangat baik. Dari luar manusia seperti Allah dalam hal kemampuan dan karakteristiknya secara fisik, dari dalam manusia dapat berpikir dan mengembangkan pemikirannya di mana hanya manusia yang dapat melakukannya. ${ }^{1}$ David Atkinson menjelaskan bahwa penciptaan manusia adalah penggenapan dan makna dari pekerjaan Allah. Kedudukan pria dan perempuan sama di mata Tuhan. Akan tetapi menurut fungsinya pria dan perempuan berbeda. Perempuan memiliki keunikan tersendiri sehingga tidak ada perempuan yang diciptakan sama. Perempuan adalah ciptaan yang indah dan berharga di mata Tuhan. ${ }^{2}$

Maka perempuan harus tetap bersyukur dan menghargai dirinya sendiri. Sudah menjadi bagian dari hidup perempuan Kristen untuk tetap bersyukur dalam segala hal, baik dalam kesulitan, atau pun senang. Bersyukur merupakan bentuk kepuasan, berarti kita juga menyatakan rasa puas kita atas semua yang sudah diputuskan Tuhan untuk kita, tidak hanya dalam hal menyenangkan namun juga hal kurang menyenangkan di dalam hidup, oleh sebab semua itu adalah keputusan Tuhan dan wajib untuk mensyukuri semuanya itu. Kebahagiaan, kenikmatan atau hal yang menyenangkan bertahan lama bukan berasal dari ucapan terima kasih saja diucapkan, tapi berasal dari hati yang dipenuhi rasa bersyukurnya.

Hasilnya, kita akan terhindar dari perasaan sombong, iri, dan kesal yang bisa membuat orang menjauhi kita dan hilangnya sukacita. Kehendak dari Tuhan dalam menciptakan adalah agar bisa menikmati bumi dan segala sesuatu yang ada didalamnya dan ini juga menjadi alasan untuk bersyukur sebab sudah diperbolehkan untuk menikmati segala sesuatu di dunia ini. Sepenuhnya hidup berada di dalam tangan Tuhan dan la jugalah yang mengendalikan seluruh hidup yang jalani di dunia ini.

Merlin R mengatakan bahwa bersyukur di dalam semua kondisi baik itu disaat bahagia, sedih, kuat, dan saat menderita, maka ini berarti sebagai orang percaya yang mengakui dan berserah penuh pada Tuhan yang memegang sepenuhnya atas kehidupan. Dengan bersyukur maka ini berarti mengakui dan mengetahui keberadaan Allah dan percaya bahwa Allah juga ikut serta turut mengambil bagian dari hidup, baik dalam segala sesuatu yang terjadi di kehidupan dan ini mengartikan harus selalu bersyukur sebab Tuhan tidak sekalipun meninggalkan walaupun terkadang bukannya

\footnotetext{
${ }^{1}$ J.D Dougls, Ensiklopedi Alkitab Masa Kini Jilid 2 (Jakarta: Yayasan Komunikasi Bina Kasih, 1995).23

${ }^{2}$ Atkinson David, Kejadian 1-11 (Jakarta: Yayasan Komunikasi Bina Kasih, 1996).47-48
} 
tidak bisa bersyukur dalam hidup ini, akan tetapi karena kita tidak mau memilih untuk bersyukur. ${ }^{3}$

Jadi setiap hari dalam kehidupan, dalam keadaan seperti apapun harus tetap mengucap syukur. 1 Tesalonika 5:18 mengatakan demikian: "Mengucap syukurlah dalam segala hal, sebab itulah yang dikehendaki Allah di dalam Kristus Yesus bagi kamu”. Allah yang menghendaki kita orang percaya untuk dapat bersyukur dalam segala hal. Dalam segala hal artinya dalam segala keadaan, apapun yang akan terjadi. Percayalah penuh kepada Allah yang selalu menjaga apapun yang terjadi. Jika dapat percaya akan pemeliharaan dan perlindungan dalam hidup ini tidak sulit untuk bisa mengucap syukur kepada Allah atas pemeliharaan-Nya.

Maka seorang wanita Kristen harus menyadari hakikatnya sebagai milik Allah. Wanita Kristen termasuk umat Allah yang telah dipanggil-Nya, ditebus dan terus dikuduskan oleh Allah sendiri. Wanita Kristen juga harus melakukan kewajiban sebagai umat Allah yaitu mendengarkan firman Tuhan dan menjadikan firman itu sebagai dasar kehidupannya secara praktis. Wanita dalam Alkitab memang hidup di masa yang lalu, dengan perbedaan zaman yang harus dihadapi oleh wanita sekarang ini. Wanita Kristen masa kini seringkali mengabaikan firman demi kepentingan diri sendiri.

Memperoleh kepuasan atau kesenangan tidaklah salah, namun seorang wanita juga harus memiliki prioritas untuk hidupnya dan hikmat dalam mengelola berkat Tuhan. Memuliakan Allah seharusnya menjadi tujuan utama di dalam kehidupan para wanita. Keintiman hubungan dengan Tuhan akan mengarahkan kaum wanita untuk melakukan yang dikehendaki oleh Tuhan hakikat wanita Kristen sebagai umat Allah membawa wanita Kristen untuk mendengar firman Tuhan dalam arti mengerti, mentaati, mengindahkan, memeriksa dan melakukannya dalam kehidupan praktis. Wanita Kristen harus memberikan perhatian khusus kepada firman dalam kehidupannya.

Persekutuan dengan orang percaya yang lain juga dapat membangun jati diri dalam Kristus melalui sesama orang percaya. Sebagi orang percaya, wanita Kristen juga harus mampu bersaksi tentang Kristus kepada orang lain secara khusus bagi yang tidak mengenal Tuhan. Manusia memang makhluk sosial yang dituntut untuk bisa bersosialisasi dengan sesamanya.

Wanita Kristen saat ini sangat mudah terpengaruh padan lingkungan sekitareli benda itu karena sungkan dengan temannya, gengsi, malu tidak mengikuti perkembangan zaman, takut tidak mempunyai teman atau komunitas wanita lagi, dan itulah yang mereka lakukan. Kurangnya rasa bersyukur dengan yang mereka miliki, tidak menikmati karena itu timbul rasa ketidak puasan dalam dirinya sehingga mengakibatkan masalah belanja adalah salah satu favorit wanita, yang memang tiap-tiap saat demi kepentingan, kepuasan dan kebahagiaan untuk saat itu

\section{METODE PENELITIAN}

Penelitian ini menggunakan memakai metode deskriptif-bibliologis adalah suatu metode atau penelitian status sekelompok manusia, atau suatu masyarakat, suatu kondisi, suatu sistem pemikiran atau peristiwa masa kini. ${ }^{4}$ Adapun tujuannya adalah untuk membuat deskripsi, gambaran atau lukisan secara sistematis faktual dan akurat mengenai fakta-fakta, sifat-sifat serta hubungan antara fenomena yang diselidiki. bahwa bibliologis didasarkan pada prinsip-prinsip Alkitab agar dapat dipertanggungjawabkan

\footnotetext{
${ }^{3}$ Carothers Merlin R., Kuasa Dalam Pengucapan Syukur (Jawa Barat: Mimery, 1978).20-23

${ }^{4}$ Sumanto, Metode Penelitian Sosial Dan Pendidikan (Yogyakarta: Andi, 1976).109
} 
secara Alkitabiah, seperti analisa teks dengan memperhatikan: sumber teks, bahasa asli teks, analisa konteks dan latar belakang konteks dan latar belakang teks guna mendapatkan makna sesungguhnya. ${ }^{5}$

\section{HASIL DAN PEMBAHASAN}

\section{HAKIKAT PEREMPUAN DALAM ALKITAB}

Dalam bagian ini penulis akan memaparkan tentang hakikat Perempuan dalam Alkitab yang meliputi: Bijaksana, mulia, Perempuan sebagai penolong bagi laki-laki.

\section{Bijaksana}

Firman Tuhan dalam Kitab Amsal 31 menuliskan bahwa istri yang cakap dan bijaksana, adalah lebih berharga dari pada permata. Hal berarti perempuan yang sangat tinggi nilainya, yang mahal, dan tidak bisa dibandingkan dengan apapun. Sebab isteri yang cakap dan yang bijaksana memiliki sifat, moral dan karakter yang mulia dan berkualitas, memiliki pengenalan yang benar akan Tuhan. Firman Tuhan dalam Kitab Mazmur 111:10 dituliskan bahwa permulaan hikmat adalah takut akan Tuhan. Sehingga seorang perempuan yang bijak, hal pertama yang perlu dilakukan adalah, takut akan Tuhan.

Pauline Youd menjelaskan bahwa seorang perempuan seharusnya bertindak bijaksana sekalipun ia pada posisi saat itu sebagai seorang pemimpin. Debora seorang nabiah istri Lapidot, ia memerintah sebagai hakim atas Israel. Debora dengan sikap rendah hati dan bijaksana mendelegasikan tugas, namun Debora juga berani mengambil tanggung jawab ketika orang yang dipimpinnya tidak mampu. Dia juga perempuan yang berani, dan sangat tegas dalam kepemimpinannya. ${ }^{6}$ Dalam Hakim-Hakim 5:1-31 ${ }^{7}$ Debora bersyukur atas pertolongan Tuhan, ayat 4-5 dengan jelas melukiskan betapa berkuasanya Tuhan. Ayat 4 bagaimana pasukan Sisera dikacaubalaukan oleh Tuhan, sedangkan ayat 5 bagaimana Tuhan memimpin bangsa Israel keluar dari Mesir. Jadi Nyanyian Debora ini bukan hanya mengingat pertolongan Tuhan di masa itu namun juga di masa lalu. Ayat 6 dan 8 menjelaskan bahwa kelemahan dan ketidakberdayaan bangsa Israel. Ketika melihat bagaimana Tuhan menolong mereka mereka menyadari betapa dahsyatnya Tuhan di tengah ketidakberdayaan mereka. Inilah yang mendasari nyanyian Debora dan Barak ini. Setiap kita dapat merasa tidak berdaya dihadapan masalah yang besar, tetapi Kesetiaan dan Kuasa-Nya adalah kekuatan dan kelepasan, asal mau mengandalkan Dia. Debora bersyukur karena Tuhan memampukan Debora memimpin bangsa Israel.

Dalam ayat 11-23 terlihat dengan jelas bagaimana Debora bersyukur bahwa Tuhan memampukan dirinya memimpin Israel. Dalam ayat 14-15 disebutkan bahwa suku Efraim, Benyamin, Makhir, Zebulon, Isakhar, dan Naftali mengikuti kepemimpinan Debora dan Barak. Walaupun ada suku-suku yang tidak ikut namun Tuhan memberikan wibawa kepada Debora untuk memimpin Israel mengalahkan musuh. Seorang wanita dimampukan Tuhan memimpin bangsa Israel, inilah yang disyukuri oleh Debora. Seringkali tidak mau melayani Tuhan karena kita merasa tidak mampu. Namun

\footnotetext{
${ }^{5}$ Subagio Andreas B, Pengantar Riset (Bandung: Yayasan Kalam Hidup, 2004).228-229

${ }^{6}$ Youd Pauline, Mengapa Debora Marah (Jakarta: BPK Gunung Mulia, 1986).2-4

7 Hakim-Hakim 5:1-31
} 
sesungguhnya bukan ketidakmampuan yang menghalangi untuk tidak melayani Tuhan namun karena kita kurang mengenal siapa Tuhan yang disembah.

\section{Mulia}

Tuhan telah memberikan janji-Nya bahwa mereka yang menerima segala sesuatu dengan rasa terima kasih akan dijadikan mulia dan apa yang dari bumi ini akan ditambahkan kepada mereka. Betapa kita akan sangat diberkati jika kita mengakui pengaruh Allah dalam kehidupan yang luar biasa. Rasa syukur kepada Bapa di surga memperluas persepsi dan memperjelas pemahaman kita. Itu mengilhami kerendahan hati dan mengembangkan empati terhadap sesama manusia dan semua ciptaan Allah. Rasa syukur adalah bagian yang diperlukan bagi semua sifat seperti Kristus hati yang penuh syukur menyertai semua kebajikan. Manusia pertama yang diciptakan langsung oleh Allah tanpa adanya hubungan jasmani dari laki-laki dan juga perempuan. Pada saat tersebut, Tuhan Allah membentuk manusia dari debu dan juga tanah lalu ia memberikan nafas hidup dan dengan demikian manusia menjadi makhluk yang hidup.Tuhan kemudian juga bersabda jika "Tidak baik jika manusia seorang diri saja, Aku akan menjadikan penolong baginya yang sepadan dengan dia" Kejadian 2:18. Sekalipun Hawa jatuh dalam dosa tetapi dia bersyukur karna masih menikmati kasih Allah, dan Hawa masih menikmati karya penyelamatan dari Allah sendiri. ${ }^{8}$

\section{Perempuan Sebagai Penolong Bagi Laki-laki}

Hakekat perempuan sejak semula diciptakan adalah sebagai penolong yang sepadan bukan untuk menguasai suami. Perempuan disebut juga sebagai seorang istri sekaligus ibu, bukan hanya bertugas mendampingi suami, namun juga diharapkan dapat berperan penuh dalam pelayanannya baik dalam keluarga, gereja dan masyarakatnya. Kedudukan seorang istri tidak mudah, bukan hanya sekedar berada di belakang suami dan mengikuti apa saja yang diperintahkan oleh suaminya. Seorang istri yang bijaksana adalah istri yang mau terlibat penuh dan berperan dalam semua persoalan kehidupan baik persoalan yang terjadi dalam keluarga maupun persoalan yang datangnya dari luar keluarga. Ketika istri menemukan sesuatu yang tidak baik, istri harus langsung merespon dengan melakukan sesuatu.

David Atkinson mengatakan bahwa Allah menyediakan Hawa akan menjadi penolong sepadan bagi Adam (Kejadian 2:18b) supaya ketidakbaikan berubah menjadi kebaikan. Dalam realitas keseharian perempuan memberikan banyak pertolongan kepada laki-laki. Bukan hanya sebagai penolong tetapi sesuai dengan tujuan penciptaan laki-laki dan perempuan di Kejadian 1:26-28, dengan tugas perempuan dalam menghasilkan keturunan. ${ }^{9}$ Kitab Amsal pasal 31 berbicara tentang istri yang cakap. Dimulai ayat 11, penulis memuji perempuan ini sebagai istri yang melakukan segalanya sesuai dengan kemampuannya untuk merawat keluarganya. Dia bekerja keras untuk menjaga keteraturan rumahnya dan keluarganya. Alkitab tidak melarang perempuan untuk bekerja di luar rumah. Namun, Alkitab mengajarkan apa yang seharusnya menjadi prioritas seorang perempuan.

Jika bekerja di luar rumah bisa menyebabkan seorang istri mengabaikan anak-anak dan suaminya, maka itu menjadi hal yang salah. Jika seorang perempuan Kristen dapat bekerja di luar rumah dan tetap masih bisa mengurus rumah tangganya sehingga

\footnotetext{
${ }^{8}$ Kejadian 2:18

${ }^{9}$ David, Kejadian 1-11.45
} 
terawat dan penuh kasih untuk anak-anak dan suaminya, maka bekerja di luar rumah diperbolehkan baginya. Billy Graham mengatakan bahwa Keluarga harus mencerminkan prinsip Kerajaan Allah. Bila cermin pemerintahan Allah ada dalam suatu rumah tanggga, berarti Yesus ada di atas suami. ${ }^{10}$

Di surat Titus 2:3-4, Paulus memberikan petunjuk mengenai bagaimana perempuan muda yang sudah menikah untuk dididik oleh perempuan yang lebih tua, mendidik perempuan-perempuan muda mengasihi suami dan anak-anaknya, hidup bijaksana dan suci, rajin mengatur rumah tangganya, baik hati dan taat kepada suaminya, agar Firman Allah jangan dihujat orang. Melalui ayat ini, Alkitab dengan jelas menyatakan bahwa ketika seorang perempuan muda sudah dianugerahi anak, itu menjadi tanggung baginya. Tetapi wewenang yang dibungkus dengan kasih Kristus demi kemuliaan Allah dan tegaknya rumah tangga Allah atau pemerintahan Allah dalam keluarga. Para perempuan yang lebih tua seharusnya mendidik para perempuan yang lebih muda ini dan menjalani kehidupan yang memuliakan Allah. Seorang isteri yang sejati harus kembali kepada fungsinya yang sejati serta memiliki kerelaan untuk taat kepada Allah. Ketika ia mulai mau menundukkan diri kepada Kristus sebagai pusat kehidupannya maka itu akan memunculkan sikap penundukan kepada suaminya dan kondisi kenaturalan kewanitaan.

Seorang istri yang tunduk kepada suami tidak berarti mencampakkan kecerdasan, ketrampilan, dan segala potensi yang dimiliki oleh seorang istri. Seorang suami atau istri jika tidak menjalankan fungsinya sesuai dengan perintah Allah, akan menghadapi kesulitan dalam kehidupan rumah tangganya. Konsep ini sudah muncul sejak di jaman Abraham, dimana Sarah begitu tunduk kepada Abraham dan memanggil suaminya sebagai tuannya. Seorang istri harus menghormati suaminya sekalipun ia tidak layak menerimanya. Dalam Petrus 3:1-6, Petrus menekankan agar para istri menghargai dan tunduk kepada suami mereka yang tidak taat kepada Firman (ayat 1).

Tunduk disini adalah tunduk yang tidak mengorbankan iman Kristen dan ketaatan kepada Firman Tuhan dan kesetiaan kepada Kristus. Dalam hal ini istri bisa menolak ajakan atau perintah suami apabila ajakan atau perintah tersebut bertentangan dengan Firman Tuhan dan merusak kesetiaan kepada Kristus. Retnowati menjelaskan Sara tentunya bukan wanita yang sempurna, tetapi dia tetap tunduk kepada Abraham. Salah satunya adalah ketika mereka melakukan perjalanan ke Mesir dan Abraham meminta Sara untuk berbohong bahwa dia adalah adik dari suaminya sendiri. Begitu pula dengan kerelaannya meninggalkan segala kepunyaannya untuk pergi bersama Abraham ke tempat yang mereka tak pernah tahu. Ketika Tuhan memanggil Abraham untuk meninggalkan segala kepunyaannya, hal itu juga diresponi dengan taat oleh Sara (Kejadian 12: 1-6). ${ }^{11}$ Sarah hadir sebagai penolong Abraham dalam membuat keputusan. Kejadian 21:12 ${ }^{12}$ Tetapi Allah berfirman kepada Abraham: "Janganlah sebal hatimu karena hal anak dan budakmu itu; dalam segala yang dikatakan Sara kepadamu, haruslah engkau mendengarkannya, sebab yang akan disebut keturunanmu ialah yang berasal dari Ishak.

\footnotetext{
${ }^{10}$ Graham Billy, Keluarga Yang Berpusatkan Kritus (Bandung: Yayasan Kalam Hidup, 1961).40

${ }^{11}$ Retnowati, Perempuan-Perempuan Dalam Alkitab : Peran, Partisipasi, Dan Perjuangannya (Jakarta: BPK Gunung Mulia, 2012).11

${ }^{12}$ Kejadian 21:12
} 


\section{Sub Judul 1}

Hasil dan pembahasan dapat disajikan menggunakan sub judul sesuai kebutuhan. Hasil dan pembahasan berisikan data yang dikumpulkan selama proses penelitian serta analisis dari data tersebut. Hasil penelitian meliputi deskripsi data yang telah dikumpulkan, analisis data, dan interpretasi data menggunakan teori yang relevan. Hasil penelitian harus jelas dan ringkas. Sementara pembahasan seharusnya mengeksplorasi hasil pekerjaan yang signifikan, bukan mengulangnya.

\section{PENYEBAB HIDUP PEREMPUAN YANG BERSYUKUR MENURUT ALKITAB}

Dalam bagian ini penulis akan memaparkan tentang pola hidup wanita yang bersyukur menurut Alkitab yang meliputi: memiliki relasi yang baik dengan Tuhan, menyadari kehadiran Allah dalam hidupnya, mencukupkan diri dalam segala sesuatu, bersyukur dalam segala keadaan.

\section{Memiliki Relasi yang Baik Dengan Tuhan}

Memiliki hubungan pribadi dengan Allah berarti harus melibatkan Allah, berarti harus berdoa kepada-Nya, membaca firman-Nya lalu melakkannya. Percaya pada Allah untuk menyertai kehidupan setiap hari dan percaya bahwa Allah pemelihara dalam hidup. Sebelum Adam berdosa di Taman Eden (Kejadian pasal 3), Adam dan Hawa mengenal Allah mereka memiliki hubungan pribadi dengan Allah dengan baik. Mereka berjalan dengan-Nya di Taman Eden dan berbicara langsung kepada-Nya. Karena dosa mereka, manusia menjadi terpisah dan terputus dari Allah.

\section{Percaya}

Menerima Yesus berarti percaya bahwa Dia adalah Anak Allah, seperti yang Dia nyatakan, dan kemudian mengundangNya untuk memimpin dan mengarahkan seluruh hidup. Alice Mathews mengatakan bahwa Yesus menemukan ditepi sumur seorang perempuan Samaria, yang mengubah hidupnya melalui perhatian-Nya terhadap perempuan itu. Kasih-Nya yang tanpa syarat memampukan seorang perempuan Samaria yang berdosa telah mempunyai lima suami, dan yang ada padanya sekarang bukan suaminya lalu percaya Yesus (Yohanes 4:19). Ketika Yesus mengajarkan kepada perempuan itu tentang Allah sebagai Bapa yaitu Allah yang disembah dalam Roh dan Kebenaran, perempuan itu segera meninggalkan tempayannya di situ dan langsung menuju kota, untuk menceritakan pengalaman rohani, dimana perjumpaan pribadinya dengan Yesus mendorong perempuan itu untuk mengimani Dia sebagai Tuhan dan menceritakan iman percayanya itu kepada orang lain. ${ }^{13}$

Kelihatannya memang terlihat sulit untuk dilakukan, tetapi mudah dilakukan ketika menjalin hubungan yang baik dan menjalin relasi dengan Allah dan menaruh kepercayaan kepada Allah. Alkitab mengatakan, tetapi semua orang yang menerimaNya diberi-Nya kuasa supaya menjadi anak-anak Allah, yaitu mereka yang percaya dalam nama-Nya. Yesus dapat memberikan arti dan tujuan hidup. Dengan demikian seharusnya orang percaya menyadari bahwa ketika melaksanakan pelayanan untuk Allah terlebih dahulu telah memberikan kuasa bagi orang percaya untuk menyampaikan kabar baik. Bukan hanya kepada hamba Tuhan melainkan kepada seluruh orang percaya untuk mengabarkan keselamatan melalui Tuhan Yesus kepada mereka yang belum percaya.

\footnotetext{
${ }^{13}$ Alice Mathews, Wanita Yang Dibimbing Yesus Teladan Bijak Dari Para Wanita Perjajian Baru (Jakarta: Duta Harapan Dunia, 1974).15
} 
William Barclay menjelaskan dalam bukunya, setiap orang percaya harus berani untuk memberitakan Injil karena itu adalah tugas dan tanggung jawab mereka yang tidak dapat ditawar-tawar lagi. Memberitakan bahwa Yesus adalah Tuhan. ${ }^{14}$

Perempuan Samaria itu sangat bersyukur bertemu dengan Yesus sehingga dia menemukan jati dirinya yang sesungguhnya, lalu percaya Yesus dan melalui peristiwa tersebut banyak orang yang percaya pada saat itu. ${ }^{15}$

\section{Berdoa}

Menurut Simon Chan istilah doa memiliki pengertian terhadap Allah dan hubungan pribadi dengan Allah dalam persekutuan dengan Allah. ${ }^{16}$ Berdoa adalah strategi yang paling dibutuhkan, dengan berdoa maka Roh Kudus akan bekerja pada seseorang yang belum percaya. Orang percaya mempunyai hak istimewa datang langsung ke hadirat Tuhan dan meminta Dia menolong manusia. Berdoa mempersilahkan Yesus turut campur dalam segala kebutuhan manusia.

Berdoa adalah memberi izin Yesus untuk menggunakan kuasa-Nya dalam meringankan kesukaran. Berdoa adalah mempersilahkan Yesus memuliakan nama-Nya ditengah-tengah kebutuhan manusia. Dengan demikian, jawaban doa, tidak tergantung pada kuasa orang yang berdoa. Kemauannya yang keras, emosi yang kuat dan pemahamannya yang jelas mengenai apa yang sedang didoakannya bukan penyebab mengapa doa-doanya didengarkan dan dijawab.

Andrew Murray mengatakan, "Sebagai wakil Tuhan di dunia, orang yang sudah ditebus dosanya mempunyai kuasa untuk menentukan sejarah dunia ini melalui kuasa doa". ${ }^{17}$ Doa merupakan salah satu cinta kasih Tuhan kepada orang percaya ialah memberikan kesempatan bagi manusia untuk mendekatkan diri kepada Tuhan walaupun manusia telah kehilangan kemuliaan, melalui doalah dapat mengikatkan hati orang percaya kepada Tuhan. Saumiman Saud mengatakan doa merupakan komunikasi yang benar, disitu orang percaya mencurahkan isi hatinya kepada Tuhan, seperti Hana waktu ia berdoa kepada Tuhan menyatakan aku mencurahkan isi hatiku dihadapan Tuhan (1 Sam. 1:15). Hana juga menyampaikan doannya pada Tuhan, bukan pada saat anaknya lahir, melainkan pada saat Hana dan Elkana memberikan anaknya Samuel untuk melayani Allah di Syilo. Jadi, Hana merasakan sukacita yang besar karena berkat yang ia terima dari Tuhan. ${ }^{18}$ Retnowati menjelaskan bahwa Ribka perempuan pendoa, sama seperti suaminya Ishak, suami istri ini sangat berhubungan dekat dengan Allah.

Mungkin Ribka mendapatkan kembali kepercayaan dirinya setelah hamil. ${ }^{19}$ Menurut J.H Gondowijoyo doa adalah hubungan timbal balik antara dua pribadi (orang percaya kepada Tuhan) dimana ada komunikasi timbal balik (dua arah) berbicara dengan spontan dan Tuhan juga berbicara kepada orang percaya (diam untuk mendengar suara Tuhan). ${ }^{20}$ jadi, di dalam doa orang percaya dapat mengungkapkan rasa syukur kepada Tuhan, memohon pimpinan Tuhan, menyampaikan pergumulan dihadapan Tuhan. Dalam Kejadian 25:22-25 Ribka selalu bersyukur dan selalu mencari Allah, berkaitan

\footnotetext{
${ }^{14}$ Barclay William, Mengkomunikasikan Injil (Jakarta: BPK Gunung Mulia, 1986).26

${ }^{15}$ Yohanes 4:39-42

${ }^{16}$ Chan Simon, Spritual Theology (Yogyakarta: Andi, 1998).11

17 Andrew Murray, Pola Hidup Kristen..., 678

${ }^{18}$ Saud Saumiman, Dinamika Kehidupan Orang Percaya (Jakarta: Yasinta, 2004).160

${ }^{19}$ Retnowati, Perempuan-Perempuan Dalam Alkitab : Peran, Partisipasi, Dan Perjuangannya.16

${ }^{20}$ Gondowijoyo J.H, Membangun Keintiman Dengan Bapa (Yogyakarta: Andi, 2007).95
} 
dengan persoalan anak-anaknya dan dia mendapatkan jawaban yang jelas dari Tuhan kerena hubungan pribadinya yang baik dengan Tuhan.

\section{Menyadari Kehadiran Allah dalam Hidupnya}

Dalam bagian ini penulis akan memaparkan tentang menyadari kehadiran Allah dalam hidupnya yang meliputi: Mencari Tuhan, sabar, tekun, tidak mudah menyerah.

\section{Mencari Tuhan}

Kualitas rohani seorang perempuan Kristen akan terus mengalami kemajuan apabila ia membaca Firman Tuhan dan memahaminya dengan segenap hati dan jiwa. Tuhan telah berfirman kepada manusia melalui Alkitab, dan manusia harus membacanya dengan cermat untuk dapat memahami maksud Firman Tuhan tersebut. Jika tidak demikian manusia tidak dapat memperoleh pesan atau maksud Allah. Dalam pembacaan Firman Tuhan itu, harus membaca dengan tekun supaya mereka semakin mengenal Allah dan petunjuk kehidupan untuk menyenangkan Allah.

Firman Tuhan adalah kebenaran. Setiap orang percaya harus meyakini hal itu, sehingga mereka harus terbuka dan menerima Firman itu sebagaimana adanya. Mereka tidak boleh memasukkan pikirannya ke dalam Firman Tuhan tersebut, namun harus menerima Firman secara murni yang akan menuntun hidup mereka. Sehingga dengan demikian dapat dikatakan bahwa tidak ada yang dapat dibanggakan dari seorang manusia, sebab manusia terbatas dan juga rapuh. Kalau kita menyadari hakikat ini, maka kita akan menjadi orang yang rendah hati yang mengakui/menghormati keberadaan dan kedaulatan Tuhan dan menghormati sesama manusia, sebab manusia pasti memerlukan pertolongan dan akan saling menolong. Dalam 1 Samuel 1:12-20 keinginan hati Hana yang tak dikabulkan menyebabkan rasa sakit yang mendalam. Namun, bukannya membiarkan rasa sakit membuatnya pahit hati kepada Tuhan, Hana malah menggunakan rasa sakit hatinya sebagai sarana untuk berdoa itulah bentuk ungkapan rasa bersyukur Hana dihadapan Tuhan, walaupun sekitarnya tidak mengetahui perasaannya pada saat itu, tetapi Hana selalu mencari Tuhan dan mengutarakan isi hatinya kepadanya. ${ }^{21}$

\section{Sabar}

Sabar selalu memandang segalnya dari sisi yang positif. Melalui kesabaran, kita tidak membiarkan diri terjerumus dalam sesuatu yang negatif. Bersabar dapat membuat jiwa lebih tenang dan damai. Tak hanya menenangkan, sabar juga dapat membuat raga menjadi lebih sehat dan terjaga. Kesabaran selalu diperlukan untuk menerima pemberian Allah. Kesabaran adalah ketabahan hati manusia yang dipadukan dengan kasih karunia Allah untuk memberi kita kemampuan mencari wajah Allah di dalam doa, tanpa menyerah, sampai kita menerima jawaban (Yakobus 5:7-8). Menurut Alkitab, orang yang rohani cenderung memperlihatkan kesabaran, dan sifat-sifat baik yang penting lainnya seperti kasih, sukacita, damai, kelembutan, dan pengendalian diri (Galatia 5:22, 23).

Retnowati mengatakan bahwa, sebagai seorang nabiah dan hakim Debora juga menjalankan kepemimpinannya sebagai penasihat bagi bangsa Israel yang bijak, dewasa, dan saleh. ${ }^{22}$ Dalam Habakuk 5:7 Debora selalu bersyukur dengan tantangan yang ada dihadapannya. Selain itu, hubungan yang baik dengan Allah membuat ia dapat

\footnotetext{
21 Samuel 1:12-20

${ }^{22}$ Retnowati, Perempuan-Perempuan Dalam Alkitab : Peran, Partisipasi, Dan Perjuangannya.25
} 
maksimal dalam kepemimpinannya penuh berani, setia, tidak kenal lelah, sabar, dan adil merupakan kepemimpinan Debora yang perlu di teladani. ${ }^{23}$

\section{Tekun}

Tekun adalah keputusan atau ketetapan hati yang kuat (teguh) untuk bersungguhsungguh, rajin, dan tuntas dalam melakukan apa pun. Orang yang tekun tidak mudah mendua hati. la adalah seorang yang berfokus, konsisten dan tidak mudah putus asa terhadap apa yang sedang dikerjakannya. Firman Tuhan menjelaskan bahwa, orang yang tekun sajalah yang akan menghasilkan buah (Luk 8:15), bahkan dengan porsi ganda (Yak. 5:11). kadang kala mengizinkan kita mengalami kesengsaraan dengan tujuan agar la dapat membentuk ketekunan di dalam diri kita. Oleh karena itu, Tuhan seringkali mengizinkan berbagai pencobaan menimpa hidup kita dengan maksud agar ketekunan dapat muncul di dalam diri kita.

Ketekunan dapat dilatih, karena hal itu adalah ketetapan hati. Sekalipun istri Ayub mendesak Ayub agar tidak bertekun lagi dalam kesalehannya, namun ia memutuskan dan menetapkan bahwa ia akan tetap tekun dalam kesalehannya (Ayb. 2:9-10). John R. Tan mengatakan sebagai orang yang sudah dinyatakan menjadi Anak Allah serta pandangan hidupnya sudah diubahkan, maka memberi yang terbaik untuk Tuhan adalah salah satu respons dan penghormatan kepada Tuhan, kasih manusia tidak dapat melebihi kasih Allah, karena Allah adalah kasih yang sejak semula telah ada. Jika sungguh-sungguh mengasihi Allah, maka orang percaya harus memberikan yang terbaik untuk Tuhan yang didasari dengan kasih yang murni. ${ }^{24}$

Retnowati menjelaskan bahwa Sara dan Abraham kurang percaya dengan janji Allah dalam keluarga mereka (Kejadian 17:17-18, 18:11-12). Dengan berkat Allah yang selalu menyertai Sara dan Abraham sekalipun tidak percaya kepada janji Tuhan. ${ }^{25}$ Dalam Kejadian 20 sarah selalu bertekun dalam menunggu janji Allah dan selalu berdoa untuk orang lain dan orang yang didoakan itu memunyai anak sekalipun Sarah tidak memilikinya, itulah ungkapan syukur sarah dia bisa berbagi terhadap sesamanya.Sarah juga tetap setia dan semakin tekun melayani Tuhan. ${ }^{26}$

\section{Tidak Mudah Menyerah}

Alkitab menegaskan bahwa terkutuklah orang mengandalkan manusia dan yang mengandalkan kekuatannya sendiri. Harus sadar bahwa kekuatan sangat terbatas. Karena itu, andalkan dan harapkanlah kekuatan dari Tuhan. Dengan begitu, maka tidak gampang menyerah di dalam Tuhan Yesus yang memberi kehidupan. harus terhubung dengan sumber kekuatan, yaitu Tuhan Yesus Kristus karena di luar Dia tidak dapat berbuat apa-apa. Oleh karena itu, harus membangun mezbah doa, pembacaan Alkitab, persekutuan, ibadah sebagi cara untuk terkoneksi dengan Tuhan Yesus.

Dengan begitu, tidak akan gampang menyerah. tetap mengandalkan Tuhan harus mengandalkan Tuhan Yesus sebab di dalam Dia cakap menanggung segala sesuatu. Mengandalkan Tuhan, karena selalu ada jalan keluar untuk setiap pergumulan. Debora mampu memegang kendali dan tidak mudah menyerah tugas dan tanggung jawabnya kepada laki-laki. Dia juga menjalankan tugasnya seorang diri saja atau melalukan

\footnotetext{
${ }^{23}$ Habakuk 5:7

${ }^{24}$ Tan John R, Dinamika Pertumbuhan Iman Kristen (Jakarta: Yasinta, 2006).103

${ }^{25}$ Retnowati, Perempuan-Perempuan Dalam Alkitab : Peran, Partisipasi, Dan Perjuangannya.11

${ }^{26}$ Kejadian 20
} 
perjuangannya. Dengan Sesama perempuan saja, dia sangat menghargai dan mau bekerja sama dengan semua orang, dalam situasi krisis yang dialami oleh bangsanya.

Dalam situasi krisis, Debora bertindak mendahului laki-laki, ia bahkan bangkit sebagai ibu di Israel . Keberanian dan tanggung jawab Debora atas kehidupan bangsa ini pantas diperhitungkan. Dalam segala hal Debora tidak melupakan kesetiaannya kepada Tuhan. Sikap inilah yang membawa Debora pada posisi yang strategis dan terhormat dalam masyarakat. ${ }^{27}$

\section{Mencukupkan Diri dalam Segala Sesuatu}

Paulus tidak sedang membanggakan diri, juga tidak sedang menghibur diri. la dapat merasa cukup dalam segala keadaan di dalam Tuhan yang memberi kekuatan kepadanya. Mencukupkan diri bukanlah hal yang mudah. Paulus sendiripun perlu sebuah proses "belajar" dalam hal ini. Seperti Paulus, kita juga bisa belajar mencukupkan diri. Mulailah dengan meminta hikmat Tuhan dalam membedakan manakah kebutuhan yang harus dipenuhi, dan mana keinginan yang harus belajar kita kendalikan.

\section{Bersyukur dalam segala Keadaan}

Mengucap syukur dalam segala hal merupakan kehendak Allah. Ini berarti walaupun sedang ditimpa masalah atau malapetaka, tetap harus mengucap syukur. Kalau tidak mengucap syukur dalam segala hal, berarti sedang tidak berada di dalam kehendak Allah, sedang mengingkari, tidak taat dan melawan kehendak Allah. Dengan tidak mengucap syukur dalam segala hal, baik sedang berada di luar jalur kehendak Allah dan sedang memberontak terhadap kehendak Allah dalam hidup. Tindakan tidak mengucap syukur adalah suatu tindakan pemberontakan yang halus terhadap Allah. Dan tidak ada pemberontak yang akan mengalami penyertaan Allah. Karena tidaklah mungkin Allah menyertai orang yang tidak taat dan melawan Allahnya. Bersyukur atau tidak itu tergantung dari respon hati. Keadaan yang ada sekarang mungkin saja tidak dapat diubah, tetapi dapat merubah respon hati. Bersyukur bukan karena tidak bisa, tetapi karena kita tidak mau memilih untuk bersyukur. Jadi setiap hari dalam, dalam keadaan seperti apapun, harus tetap mengucap syukur. Dalam Lukas 8:2-3 Maria Magdalena bersyukur atas pertolongan Tuhan ketika dibebaskan dari roh-roh jahat. Dia hanya sekali mengalami pertolongan Tuhan, tetapi pertolongan itu memberi perbedaan yang besar atas hidupnya. Ada banyak orang yang sudah merasakan campur tangan Tuhan, bahkan mengalami mujizat demi mujizat tetapi tidak juga menunjukkan syukurnya dengan berlaku setia kepada Tuhan. ${ }^{28}$

\section{KRITERIA-KRITERIA WANITA YANG BERSYUKUR MENURUT ALKITAB}

Dalam bagian ini penulis akan memaparkan tentang kriteria-kriteria wanita yang bersyukur menurut Alkitab yang meliputi: dikehendaki Tuhan, menjadi Teladan, harus Melayani

\section{Dikehendaki Tuhan}

Hal yang dikehendaki Tuhan pada manusia yaitu dalam beribadah akan terjadi persekutuan yang intim antar manusia dengan Tuhan, dimana orang percaya dapat

\footnotetext{
${ }^{27}$ Habakuk 5:7

${ }^{28}$ Lukas 8:2-3
} 
memberi respons dengan kerendahan hati menyatakan penghormatan dan kekaguman terhadap Tuhan. Eka Darmaputera mengatakan bahwa di dalam ibadah Allah yang menjadi pusat pujian yang disembah oleh orang percaya. ${ }^{29}$ Ibadah yang menyangkut sikap hati orang percaya yang penuh dengan bersyukur, orang percaya bukan hanya rajin dalam persekutuan dan beribadah kepada Tuhan, tetapi melalui persekutuan itu, kehidupan orang percaya diubahkan, pola pikir diubahkan, tindakan diubahkan, sehingga melalui beribadah Tuhan menyatakan kehendak-Nya kepada orang percaya. Phen F. Olford menjelaskan bahwa Penyerahan total berarti tidak boleh mengendalikan diri sendiri, tetapi membiarkan Allah mengungkapkan rencana-Nya, memimpin, dan mengarahkan kehidupan orang percaya, mempercayakan diri kepada janji Tuhan. ${ }^{30}$

Firman Allah sebagai sumber pimpinan ilahi dalam setiap aspek kehidupan orang percaya, melalui Firman itu Tuhan menyatakan pikiran dan kehendak-Nya bagi kehidupan manusia. Menurut Christian Weiss Alkitab adalah firman Allah yang tak dapat salah, yang dapat dipercayai dan abadi, kenyataan yang sempurna dari pikiran ilahi dan hati Allah, dan kehendak-Nya bagi kehidupan setiap orang yang percaya kepada-Nya. ${ }^{31}$ J. Verkuyl menjelaskan bahwaAlkitab adalah firman Allah sebagai tulisan yan diilhamkan oleh Allah (II Timotius 3:16). Alkitab merupakan media Allah untuk menyatakan diri-Nya kepada orang percaya. Melalui Alkitab setiap orang percaya dapat mengetahui sesuatu tentang Allah, sejauh Allah menyatakan diri-nya, melalui Alkitab. ${ }^{32}$ Dalam Lukas 1: 46-56 Maria seorang perempuan yang selalu bersyukur, dia memuliakan Tuhan dengan segenap jiwanya. Kesederhanaan dan ketulusan iman dalam keluarganya sungguh membentuk Maria menjadi pribadi yang juga sangat sederhana, menjadi wanita suci dan saleh, mencintai sesama dan hidupnya selalu berpasrah pada kehendak Tuhan. Hidup Maria sepenuhnya berserah pada kehendak Tuhan, maka Tuhan akan melimpahkan rahmatNya, bahkan rahmat yang mungkin tak pernah diduga atau sebuah rahmat besar yang tak terpikirkan atau terjangkau oleh manusia. Hal ini sungguh dialami oleh Maria. ${ }^{33}$

\section{Menjadi Teladan}

Teladan seorang perempuan yang paling penting yang dapat dia berikan ialah, menerima Kristus sebagai Juruselamat pribadinya, mengakui Dia di hadapan orangorang lain dan hidup penuh dedikasi kepada Kristus. Anisah Zakiah mengatakan bahwa Bertumbuh tanpa keteladanan seorang perempuan mendatangkan resiko yang serius bagi keluarga. Maka tidak heran jika kebiasaan perempuan sering kali ditiru oleh anakanaknya. 34 Jadi, penting sekali bagi seorang perempuan untuk dapat menjadi teladan dalam sikap maupun kepribadian hidupnya bagi keluarga dan sesame juga.

Dengan demikian, Allah akan berkenan atas hidupnya. Harus tetap bertahan dalam hidup baru dan imannya kepada Tuhan. Setia pada komitmen dan memiliki iman yang teguh adalah bukti dari pemulihan, sehingga dapat bertahan dalam kondisi hidup yang baru dan komitmen untuk menjadi anak Allah, dan sampai pada akhirnya menjadikan ini suatu penerimaan yang kuat untuk dapat bertumbuh didalam Kristus. Oleh karena itu, kaum perempuan harus menjadi teladan yang baik. Para kaum perempuan harus menunjukkan jalan yang benar kepada anak-anak remaja mereka dalam kehidupan

\footnotetext{
${ }^{29}$ Darmaputera Eka, Menuju Hidup Berkemenangan (Jakarta: BPK Gunung Mulia, 2005).37

${ }^{30}$ Olford Stephen F., Melangkah Maju Bersama Allah (Bandung: Yayasan Kalam Hidup, 1983).132

${ }^{31}$ Weiss Christian, Mencari Kehendak Allah (Surabaya: Yakin, 1987). 80

32 J. Verkuyl, Aku Percaya (Jakarta: BPK Gunung Mulia, 1995).21

33 Lukas 1: 46-56

${ }^{34}$ Zakiah Anisah, Ayah Mengasuh Anak? Kenapa Tidak? (Yogyakarta: Java Litera, n.d.).18
} 
sehari-hari, Yesus mengajar murid-muridNya dengan perkataan dan melalui teladan. Maka, kaum wanita haruslah menjadi teladan untuk sesama sama seperti Kristus yang sudah memberikan teladan.

Alice Mathews mengatakan bahwa Lidia percaya kepada Tuhan, ia dan seisi rumahnya percaya Allah dan dibaptis. Kemudian ia membuka rumahnya menjadi tempat berkumpul bagi jemaat-jemaat lain. Paulus dan rekan-rekannya dapat mengabarkan Injil dan menguatkan iman jemaat karena keramah-tamahannya, yang diberikan di sela-sela kesibukan jadwal usahanya (Kis. 16:15, Kis. 16:40). ${ }^{35}$ Dalam Kis 16:15 Lidia memberikan teladan yang begitu baik sehingga belakangan Paulus menulis kepada gereja yang sudah berdiri di Filipi berterima kasih kepada jemaat atas kebaikan hati dan dukungan mereka (FIp. 4:14-20). Lidia bersyukur bisa membawa seisi rumahnya percaya kepada Yesus ${ }^{36}$

Wilson Nadeak menjelaskan bahwa Debora memberikan teladan kepada banyak perempuan untuk dapat berperan dengan berani sebagai pemimpin sekaligus ibu yang adil, bijaksana, dan rela mempertaruhkan hidupnya untuk orang-orang yang dipimpinnya. Keteladanan lainnya yang dapat dipelajari dari Debora ialah sebagai pemimpin Debora menggerakkan bangsanya untuk tetap berharap pada Tuhan. Debora juga lebih banyak bertindak dengan petunjuk Tuhan dan menyesuaikannya dengan naluri seorang ibu yang rendah hati tetapi dengan kekuatan rohani yang peka dengan jasmani yang kuat. 37

\section{Harus Melayani}

Tuhan kita memberi teladan dalam pelayanannya bagi kita. Markus 10:42-45 menyebutkan, tetapi Yesus memanggil mereka lalu berkata, kamu juga mereka juga disebut juga pemerintahan bangsa-bangsa memerintah rakyatnya dengan tangan besi, dan pembesar-pembesar menjalankan kuasaya dengan keras atas mereka. Tidaklah demikian diantara kamu. Barang siapa menjadi pelayanmu, dan barangsiapa ingin menjadi hamba untuk semuanya. (Markus 10: 42-45) mengatakan demikian: "Karena Anak Manusia juga bukan datang untuk dilayani dan untuk memberikan nyawaNya menjadi tebusan bagi banyak orang".

Rev. Yap Un Han mengatakan manusia yang telah diselamatkan Tuhan, memiliki kerinduan untuk tetap dekat dengan Tuhan, menjaga kekudusan hidup di hadapan Tuhan, juga ada begitu banyak yang meresponi karya penyelamatan itu dengan melayani Tuhan, baik melayani Tuhan dengan separuh waktu atau sepenuh waktu bergantung bagaimana panggilan Tuhan untuk masing-masing. ${ }^{38}$ Melayani di bagian apapun itu bergantung pada panggilan Tuhan. Maka, tidak satupun dapat menjadi alasan bagi manusia untuk tidak melayani Tuhan, karena jika Allah memanggil untuk melayani, maka Allah sendiri akan memampukannya. Jadi yang berhak untuk melayani Tuhan bukan hanya laki-laki saja melainkan kaum wanita juga.

Dalam Alkitab banyak contoh-contoh dan bukti bahwa para perempuan juga dipakai dan dipanggil oleh Allah untuk melayani. Antara lain: Hawa (Kej. 1), Maria (Luk. 1 dan 2), Hagar dan Sara (Kej. 12) Ribka (Kej. 24), Rut (Rut. 1), Hana (Luk. 2), Debora (Hak. 5), Marta (Luk. 10), Lea dan Rahel (Kej. 29), Naomi (Rut. 1), Ester (Est.1), Safira (Kis. 5), Maria Magdalena (Yoh. 19), Janda Miskin (Luk. 21), Perempuan yang berzinah (Yoh. 8),

\footnotetext{
${ }^{35}$ Alice Mathews, Wanita Yang Dibimbing Yesus Teladan Bijak Dari Para Wanita Perjajian Baru.166

${ }^{36}$ Kisah Para Rasul 16:15

${ }^{37}$ Nadeak Wilson, Perempuan-Perempuan Pemberani (Bandung: Lembaga Literatur Baptis, 2005).47

${ }^{38}$ Yap Un Han Rev, Problematika Hamba Tuhan (Manado: Yayasan Daun Family, 1998).57-58
} 
perempuan di tepi sumur Yakub (Yoh. 4), dan perempuan-perempuan teman sekerja Paulus (Kis. 16, 18). 39 Kemampuan para perempuan a ini tidak semua sama tetapi Allah memakai mereka sesuai dengan kapasitas mereka masing-masing dengan bentuk pelayanan yang berbeda tetapi memiliki tujuan yang sama yaitu untuk memuliakan Tuhan.

Keberadaan hidup orang percaya yaitu untuk melayani Kristus melalui orang-orang yang ada di sekitarnya. Pelayanan yang dilakukan tidak pandang usia, kasihnya merata sesuai dengan yang Tuhan perintahkan yaitu kasihilah sesamamu seperti dirimu sendiri (Mat. 22:37-40). Demikianlah yang Tuhan harapkan untuk dilakukan oleh orang percaya melalui teks Filipi 1: 21. Petrus Octavianus menjelaskan bahwa orang percaya hendaklah melayani dan memiliki sikap saling memberi, sehingga pada waktu orang percaya melayani dan memberi dengan tidak menghitung-hitung sejumlah yang di berikan kepada Tuhan, maka akan terpancar mentalitas melayani sebagai suatu karakter yang indah, karena melayani dan memberi dengan sukarela.

Pelayanan yang dilakukan penuh dengan pengabdian diri, tanpa mencari keuntungan diri-sendiri. ${ }^{\circ 0} \mathrm{Hal}$ tersebut menjadi dasar jiwa dan penguatan bagi hambahamba Tuhan dan orang-orang Kristen yang telah percaya kepada Tuhan. Tugas pelayanan kaum perempuan ditafsirkan sebagai pelayanan Kristen, maka hal itu bukan saja menghambat wujud pemahaman yang tepat tentang yang tepat tentang pekerjaan itu, tetapi sekaligus juga merupakan kesalahan menafsirkan makna pelayanan Kristus itu. Penafsiran itu menyediakan penilaian teologis yang palsu atas penindasan perempuan melalui apa yang disebut etika pelayanan. Pelayanan ini menekankan nilai mengorbankan diri seseorang dalam pelayanan, tanpa mengeluh dan tanpa mencari imbalan. Permasalahan yang timbul bukan semata-mata karena kasih dan pengorbanan diri itu salah, tetapi karena kasih dan pengorbanan itu disalahpahami.

Anne Borrowdale mengatakan, sebenarnya kualitas-kualitas itu (kasih dan pengorbanan) tidak perlu ditekankan bagi perempuan, bukan seedar kabar baik yang disampaikan kepada seseorang yang berupaya keluar dari kelas pelayanan melainkan bahwa Allah telah memangggil untuk menjadi seorang pelayan. ${ }^{41}$ Banyak dari masalah yang dihadapai perempuan dalam pekerjaan pelayanan mereka timbul karena ada suatu perbandingan yang salah diantara respons yang mereka harapkan atau ingingkan dengan apa yang sebenarnya mereka terima. Perempuan mungkin melakukan suatu pekerjaan dengan keinginan untuk mnunjukkan kasih. Tentang hal itu, Beverly Lahaye menuliskan bahwa:

Di dalam pelayanan Kristen ada tempat yang cocok untuk setiap wanita, tidak menjadi soal apapun karunianya, memang ada orang-orang tertentu yang tidak akan dapat melakukan suatu pekerjaan, namun dia bisa melakukan halhal yang lain yang mungkin tidak bisa dilakukan oleh orang lain. Tetapi biasanya kita terlalu cepat memberi respon bahwa kita tidak dapat melakukan sesuatu pekerjaan sebelum kita mengadakan konsultasi dengan Allah Bapa yang di sorga untuk mengetahui apakah Dia menghendaki saya melakukan hal itu. ${ }^{42}$

\footnotetext{
${ }^{39}$ Retnowati, Perempuan-Perempuan Dalam Alkitab : Peran, Partisipasi, Dan Perjuangannya.53-57

40 Petrus Octavianus, Hidupku untuk Tuhan dan Sesama,..,32

${ }^{41}$ Borrwdale Anne, Tugas Rangkap Wanita (Jakarta: BPK Gunung Mulia, 1993).62-63

${ }^{42}$ Beverly Lahaye, Wanita Bahagia (Bandung: Kalam Hidup, n.d.). 157
} 
Petrus Oktavianus menjelaskan Tuhan telah memanggil dan memilih seseorang untuk melayani dan tidak ada yang dapat menghalanginya, sebab bukan manusia yang memilih untuk melayani Tuhan melainkan Tuhan memilih untuk melayani, sehingga tidak ada yang dapat menghalanginya. Tuhan memilih siapa saja yang Dia inginkan untuk melayani Dia. ${ }^{43} \mathrm{Hal}$ ini sangat jelas dalam Yohanes 15: 16 yang tertulis demikian: " Bukan kamu yang memilih aku tetapi Akulah yang memilih kamu, dan menetapkan kamu, supaya kamu pergi dan menghasilkan buah dan buahmu itu tetap, supaya apa yang kamu minta kepada Bapa dalam nama-Ku diberikan-Nya kepadamu" jadi seorang pelayan, kaum perempuan sekalipun, harus menyadari dirinya adalah pilihan Tuhan yang dipanggil untuk melakukan satu tugas yakni melayani Tuhan dalam kebenaran.

Oleh karena itu hendaknya seorang perempuan memiliki kerinduan dan dan motivasi yang murni untuk melayani Tuhan bukan karena ada motivasi-motivasi yang lain melainkan hanya untuk memuliakan Tuhan. Tetapi seringkali nilai dan motivasi pelayanan kaum perempuan tidak lagi untuk memuliakan Tuhan melainkan sudah bergeser, diganti dengan melayani diri sendiri dan melayani keluarga. Motivasi melayani Tuhan bahkan kasih Tuhan diganti dengan mengasihi diri sendiri. Etika pelayanan menekankan nilai mengorbankan diri seseorang dalam pelayanan, tanpa mengeluh dan tanpa mencari imbalan. Permasalah yang timbul bukan semata-mata karena kasih dan pengorbanan diri itu salah, tetapi karena kasih dan pengorbanan itu disalahpahami.

Sebenarnya kualitas-kualitas itu (kasih dan pengorbanan) tidak perlu ditekankan bagi wanita. Bukan sekedar kabar baik yang disampaikan kepada seseorang yang berupaya keluar dari kelas pelayanan, melainkan bahwa Allah telah memanggilnya menjadi seorang pelayan. Dalam etika pelayanan untuk melayani seorang Kristen yang benar harus dilakukan tanpa mengeluh. Pekerja yang marah terhadap kondisi kerja atau frustasi dalam pekerjaannya bukalah seorang Kristen yang baik. Seorang Kristen yang baik menerima penderitaan sebagai bagian dari penderitaan Krristus. Seorang yang baik tidak berniat untuk mengecam yang lain.

Anne Borrowdale mengatakan seorang pelayan yang baik akan patuh kepada perintah yang diperintahkan atasannya. Perempuan yang melayani Tuhan tidak menonjolkan diri dan hidup dalam kesederhanaannya. ${ }^{44}$ Perempuan Allah memiliki hak istimewa di dalam gereja beserta peran dan tanggung jawab yang terkandung di dalamnya, yaitu berperan dalam kehidupan yang kudus, berperan dalam persekutuan, kesaksian dan penyembahan. Kekudusan harus menjadigaya hidup perempuan Allah sehingga kehidupan Yesus bersinar melalui kehidupannya, kekudusan tidak pernah menunjukkan kepuasan diri terhadap dosa, melainkan menunjukkan kehidupan pribadi dan gereja dimana Yesus adalah pusat dari seluruh kegiatan hidupnya. Menjadi perempuan Allah mengharuskan untuk dapat hidup berbeda, hidup sesuai dengan standard dan peraturan yang berbeda dengan dunia. Perempuan mempunyai hak dan kesempatan yang sama, menyia-nyiakan hak dan kesempatan pemberian Allah sama dengan menyia-nyiakan berkat-Nya.

Karena itu, gereja dipanggil untuk memberdayakan kemampuan dan keahlian perempuan agar semakin hari semakin berkualitas. Di sisi lain, perempuan sendiri diingatkan bahwa panggilan iman kristiani menentang dirinya untuk berkarya dan menyumbangkan kemampuannya secara penuh. Alice Mathews menjelaskan dalam

\footnotetext{
${ }^{43}$ Oktavianus Petrus, Pendidikan Teologyi Injil Suatu Alternatif, Profil Hamba Tuhan Abad XXI Dalam Konteks Pembangunan Di Indonesia (Malang: Tunggal Murni, 1995).24

${ }^{44}$ Borrowdale Anne, Tugas Rangkap Wanita (Jakarta: BPK Gunung Mulia, 1993).62-63
} 
Lukas 10:38-42 ketika Yesus dan murid-murid-Nya dalam perjalanan, tibalah la di sebuah kampung. Seorang perempuan yang bernama Marta menerima Dia di rumahnya. Maria adalah cerminan dari orang percaya yang tahu mengambil sikap dan merespon kedatangan Yesus dengan mengambil bagian dalam hadirat Allah dengan duduk dekat kaki Tuhan dan mendengarkan perkataan-Nya.

Ini adalah sikap yang baik yang Tuhan inginkan, dimana ketika berkesempatan untuk memuliakan Allah melalui apa saja yang berkenan bisa dilakukan baik itu melalui pelayanan pribadi ataupun keluarga, harus meninggalkan kesibukan-kesibukan kita yang lain. Berbeda dengan yang di lakukan oleh Marta, saudara Maria, dimana Marta diceritakan sibuk dengan hal-hal yang tidak menjadi prioritas. ${ }^{45}$ Sungut-sungut atau protes tak jelas seringkali menghambat kinerja dalam melakukan sesuatu hal. Kesibukan yang Marta lakukan justru mendapat protes dari Tuhan. Sebagai orang yang mengasihi Tuhan Yesus kita seharusnya menyambut Yesus dalam segala hal. Menyambut bukan sekadar perkataan namun juga perbuatan. Melayani Tuhan secara pribadi adalah pondasi untuk melayani pekerjaan Tuhan. Apabila seseorang mau melayani pekerjaan Tuhan tetapi tidak memiliki waktu untuk melayani Tuhan secara pribadi, bisa dikatakan bahwa pelayanannya adalah nol. Bisa jadi dia melayani bukan untuk menyenangkan Tuhan lagi motivasinya. Itu berarti dia mulai mencari popularitas di hadapan manusia, pujian manusia dan sejenisnya.

\section{UPAYA YANG HARUS DILAKUKAN WANITA HEDONIS}

Mengantisipasi merupakan cara untuk menghindari diri dari hal-hal yang tidak sesuai dengan apa yang benar, secara khusus dalam bagian ini supaya wanita GPIN Elohim Bekasi tidak menjadi wanita yang tidak bersyukur, sehingga dalam bagian ini, penulis akan memaparkan tentang mengantisipasi penyebab hidup wanita yang tidak bersyukur.

\section{Penyerahan Diri Secara Totalitas Sebagai Alat Kristus}

Setiap wanita Kristen harus memahami jati dirinya dalam Kristus. Tuhan telah memberikan Anak-Nya yang tunggal untuk menebus dosa manusia. manusia berdosa telah ditebus dan dikuduskan oleh Tuhan dalam tiap-tiap harinya. la juga adalah ahli waris kerajaan Allah dan ia harus hidup selayaknya anak Raja sehingga orang lain melihat Kristus dalam kehidupannya tiap hari. Membangun jati diri dalam Kristus dilakukan atas ketetapan Kristus dalam firman Tuhan. Persekutuan dengan orang percaya yang lain juga dapat membangun jati diri dalam Kristus melalui sesama orang percaya.

Sebagi orang percaya, wanita Kristen juga harus mampu bersaksi tentang Kristus kepada orang lain. Kaum wanita harus menyerahkan diri secara totalitas sebagai alat Kristus. Penyerahan diri secara totalitas akan menghasilkan suatu pelayanan yang berpusat kepada Kristus, bukan berpusat pada kesenangan atau kemuliaan diri sendiri. Penyerahan diri secara totalitas mengakibatkan kaum wanita bersedia dipakai Tuhan sebagai alat-Nya kapanpun dan dimanapun.

\section{Rendah Hati}

Retnowati menjelaskan Sara tentunya bukan wanita yang sempurna, tetapi dia tetap tunduk kepada Abraham. Salah satunya adalah ketika mereka melakukan perjalanan ke Mesir dan Abraham meminta Sara untuk berbohong bahwa dia adalah

\footnotetext{
${ }^{45}$ Alice Mathews, Wanita Yang Dibimbing Yesus Teladan Bijak Dari Para Wanita Perjajian Baru.55-59
} 
adik dari suaminya sendiri. Begitu pula dengan kerelaannya meninggalkan segala kepunyaannya untuk pergi bersama Abraham ke tempat yang mereka tak pernah tahu. Ketika Tuhan memanggil Abraham untuk meninggalkan segala kepunyaannya, hal itu juga diresponi dengan taat oleh Sara (Kejadian 12: 1-6)..$^{46}$ Tidaklah salah jika seorang wanita memiliki kekuasaan atau seorang wanita memiliki pangkat dalam dunia pekerjaannya, tetapi kekuasaan itu haruslah diseimbangkan dengan pola hidup yang benar dihadapan Tuhan.

Sikap yang harus dimiliki oleh wanita Kristen yang memiliki kedudukan adalah tetap rendah hati. Kerendahan hati ini nampak dari keadilan yang dimiliki dalam hal mengasihi, memberikan hak dan kewajiban yang sesuai atau menentukan suatu perkara dengan tepat dan sesuai dengan ketetapan yang berlaku. Wanita Kristen hendaklah senantiasa bersyukur setiap waktu karena Tuhan telah memberkatinya dalam status sosial yang terpandang. Status sosial itu diberikan Tuhan dengan tujuan tertentu yaitu menjadi berkat bagi orang lain, terutama orang yang memiliki kedudukan sosial yang lebih rendah.

\section{Menolak Perkembangan Zaman yang Negatif}

Mengikuti perkembangan zaman tidak salah, tetapi harus diimbangi oleh tujuan yang jelas supaya tidak menyimpang. Hendaklah seorang manusia memiliki pusat yang kuat yaitu Kristus sehingga ia tidak perlu khawatir terhadap tantangan zaman. Allah memanggil umat-Nya dengan tujuan yang jelas dan la hendak memakai umat-Nya. ${ }^{47}$ Dengan memiliki tujuan yang jelas, maka seorang wanita Kristen memiliki komitmen yang jelas sehingga ia tidak mudah terpengaruh oleh situasi masa kini yang memiliki dampak negatif.

Tujuan hidup juga memberi koridor yang jelas dalam kehidupan seorang wanita Kristen dalam menjalani kehidupannya tiap-tiap hari dengan standart hidup yang jelas sehingga dapat mengevaluasi kehidupannya disaat ia sudah mulai membelok dari tujuan awal dan berbalik kepada tujuan yang seharusnya. Retnowati menjelaskan seorang nabiah dan hakim Debora juga menjalankan kepemimpinannya sebagai penasihat bagi bangsa Israel yang bijak, dewasa, dan saleh dan kuat di dalam Tuhan (Habakuk 5:7). Selain itu, hubungan yang baik dengan Allah membuat ia dapat maksimal dalam kepemimpinannya penuh berani, kuat menghadapi musuh didepannya, setia, tidak kenal lelah, sabar, dan adil merupakan kepemimpinan Debora yang perlu di teladani. ${ }^{48}$ Rick Warren menjelaskan tujuan hidup seorang Kristen adalah melayani Tuhan, maka keseluruhan hidupnya hendaklah diberikan kepada Tuhan juga. Hendaklah seorang manusia memiliki pusat yang kuat yaitu Kristus sehingga ia tidak perlu khawatir terhadap tantangan zaman. Allah memanggil umat-Nya dengan tujuan yang jelas dan la hendak memakai umat-Nya. 49

Dengan memiliki tujuan yang jelas, maka seorang wanita Kristen memiliki komitmen yang jelas sehingga ia tidak mudah terpengaruh oleh situasi masa kini yang memiliki dampak negatif. Tujuan hidup juga memberi koridor yang jelas dalam kehidupan seorang wanita Kristen dalam menjalani kehidupannya tiap-tiap hari dengan

\footnotetext{
${ }^{46}$ Retnowati, Perempuan-Perempuan Dalam Alkitab : Peran, Partisipasi, Dan Perjuangannya.11

${ }^{47}$ Warren Rick, The Purpose Driven Life (Malang: Gandum Mas, 2006).345-353

${ }^{48}$ Retnowati, Perempuan-Perempuan Dalam Alkitab : Peran, Partisipasi, Dan Perjuangannya.25

${ }^{49}$ Rick, The Purpose Driven Life.345-353
} 
standart hidup yang jelas sehingga dapat mengevaluasi kehidupannya disaat ia sudah mulai membelok dari tujuan awal dan berbalik kepada tujuan yang seharusnya.

\section{SIMPULAN}

Karya keselamatan dan pemeliharaan Allah dalam kehidupan setiap kaum wanita merupakan suatu anugerah yang luar biasa, oleh karena itu selayaknya setiap kaum wanita bersyukur kepada Tuhan atas segala anugerah-Nya. Namun kaum wanita tidak terlepas dari problematika yang dapat membuat mereka meragukan akan rencana Allah. Menyikapi problematika kaum wanita dalam bersyukur, maka setiap kaum wanita perlu memahami makna hidup bersyukur yang sesunggnya yaitu memuliakan Tuhan.

Debora juga menjalankan kepemimpinannya sebagai penasihat bagi bangsa Israel yang bijak, dewasa, dan saleh (Habakuk 5:7). Selain itu, hubungan yang baik dengan Allah membuat ia dapat maksimal dalam kepemimpinannya penuh berani, setia, tidak kenal lelah, sabar, dan adil merupakan kepemimpinan Debora yang perlu di teladani. Hana berdoa kepada Tuhan menyatakan aku mencurahkan isi hatiku dihadapan Tuhan, Ribka perempuan pendoa, sama seperti suaminya Ishak, suami istri ini sangat berhubungan dekat dengan Allah. Sara dan Abraham kurang percaya dengan janji Allah dalam keluarga mereka, teladan Debora dalam melayani, Sara tentunya bukan wanita yang sempurna, tetapi dia tetap tunduk kepada Abraham, inilah yang harus dimiliki kaum wanita di GPIN Elohim Bekasi Utara.

Kaum wanita harus menjadi figur pelayan yang menjadi berkat dan memiliki prinsip yang benar dalam bersyukur didalam Tuhan. Dengan demikian akan berdampak positif bagi banyak orang dan memuliakan nama Tuhan. Maka hendaklah seluruh wanita Kristen menyadari hakekatnya yang istimewa dan memposisikan diri sebagai umat Allah yang berharga. Hikmat Allah diperlukan untuk mengevaluasi pola hidup masa kini yang sedang berkembang. Arus zaman membawa manusia kepada tawaran-tawaran duniawi yang menggiurkan, namun wanita Kristen harus mampu berkata tidak terhadap pengaruh negatif yang ditimbulkan oleh perkembangan zaman.

Wanita Kristen juga harus menjadi seorang istri yang mampu menghormati suami dan mendukung suami dalam kehidupan takut akan Tuhan. Tuhan telah memberikan teguran kepada wanita dalam hal pola hidupnya, maka wanita masa kini juga harus berani mengubah pola hidup yang selama ini salah dan memperbaharuinya sehingga menjadi pribadi yang baru dan menyukakan hati Tuhan dan sesama. 


\section{DAFTAR PUSTAKA}

Alice Mathews. Wanita Yang Dibimbing Yesus Teladan Bijak Dari Para Wanita Perjajian

Baru. Jakarta: Duta Harapan Dunia, 1974.

Anisah, Zakiah. Ayah Mengasuh Anak? Kenapa Tidak? Yogyakarta: Java Litera, n.d.

Anne, Borrowdale. Tugas Rangkap Wanita. Jakarta: BPK Gunung Mulia, 1993.

Anne, Borrwdale. Tugas Rangkap Wanita. Jakarta: BPK Gunung Mulia, 1993.

Billy, Graham. Keluarga Yang Berpusatkan Kritus. Bandung: Yayasan Kalam Hidup, 1961.

Christian, Weiss. Mencari Kehendak Allah. Surabaya: Yakin, 1987.

David, Atkinson. Kejadian 1-11. Jakarta: Yayasan Komunikasi Bina Kasih, 1996.

Dougls, J.D. Ensiklopedi Alkitab Masa Kini Jilid 2. Jakarta: Yayasan Komunikasi Bina Kasih, 1995.

Eka, Darmaputera. Menuju Hidup Berkemenangan. Jakarta: BPK Gunung Mulia, 2005.

F., Olford Stephen. Melangkah Maju Bersama Allah. Bandung: Yayasan Kalam Hidup, 1983.

J.H, Gondowijoyo. Membangun Keintiman Dengan Bapa. Yogyakarta: Andi, 2007.

Lahaye, Beverly. Wanita Bahagia. Bandung: Kalam Hidup, n.d.

Pauline, Youd. Mengapa Debora Marah. Jakarta: BPK Gunung Mulia, 1986.

Petrus, Oktavianus. Pendidikan Teologyi Injil Suatu Alternatif, Profil Hamba Tuhan Abad XXI Dalam Konteks Pembangunan Di Indonesia. Malang: Tunggal Murni, 1995.

R., Carothers Merlin. Kuasa Dalam Pengucapan Syukur. Jawa Barat: Mimery, 1978.

R, Tan John. Dinamika Pertumbuhan Iman Kristen. Jakarta: Yasinta, 2006.

Retnowati. Perempuan-Perempuan Dalam Alkitab : Peran, Partisipasi, Dan

Perjuangannya. Jakarta: BPK Gunung Mulia, 2012.

Rev, Yap Un Han. Problematika Hamba Tuhan. Manado: Yayasan Daun Family, 1998.

Rick, Warren. The Purpose Driven Life. Malang: Gandum Mas, 2006.

Saumiman, Saud. Dinamika Kehidupan Orang Percaya. Jakarta: Yasinta, 2004.

Simon, Chan. Spritual Theology. Yogyakarta: Andi, 1998.

Subagio Andreas B. Pengantar Riset. Bandung: Yayasan Kalam Hidup, 2004.

Sumanto. Metode Penelitian Sosial Dan Pendidikan. Yogyakarta: Andi, 1976.

Verkuyl, J. Aku Percaya. Jakarta: BPK Gunung Mulia, 1995.

William, Barclay. Mengkomunikasikan Injil. Jakarta: BPK Gunung Mulia, 1986.

Wilson, Nadeak. Perempuan-Perempuan Pemberani. Bandung: Lembaga Literatur Baptis, 2005. 